Article

\title{
Impact on Combustion and Emissions of Jet Fuel as Additive in Diesel Engine Fueled with Blends of Petrol Diesel, Renewable Diesel and Waste Cooking Oil Biodiesel
}

\author{
Giancarlo Chiatti, Ornella Chiavola * (1) and Fulvio Palmieri \\ Engineering Department, ROMA TRE University, via della vasca navale, 79, 00146 Rome, Italy \\ * Correspondence: ornella.chiavola@uniroma3.it
}

Received: 31 May 2019; Accepted: 26 June 2019; Published: 28 June 2019

check for updates

\begin{abstract}
This study is devoted to investigating the potential use of Jet A in blend along with biodiesel from waste cooking oil, petrol diesel, and renewable diesel. Biodiesel use allows for reducing carbon monoxide (CO), unburned hydrocarbons ( $\mathrm{HC})$, and soot due to the oxygen contained in the fuel. The drawbacks in its use are related to the low volatility and high viscosity of vegetable oil that cause difficulties in fuel atomization and in its mixing with air. Moreover, an increased amount of $\mathrm{NO}_{\mathrm{x}}$ emission was observed. The aim of the experimentation is to evaluate the ability of Jet A of enhancing the combustion process and pollutant emissions of a diesel engine, thus overcoming the difficulties in biodiesel usage (high viscosity, poor cold weather performance, compatibility with diesel engine equipment) and then increasing the renewable fuel percentage in the fuel. Testing was carried out on a small displacement common rail diesel engine. Hardware and ECU setting were not modified in order to let the engine be ready to operate with different and exchangeable fuels. The effect on pollutant emissions of a variation of the amount of Jet A and biodiesel in the fuel is investigated, while accounting for the engine speed value.
\end{abstract}

Keywords: diesel engine; emissions; biodiesel; waste cooking oil; renewable diesel; jet fuel

\section{Introduction}

The exhaust emissions of internal combustion engines significantly contribute to the environmental degradation of the urban area. Environmental sustainability, economic, and social concerns have motivated researchers to examine and evaluate the performance of alternative fuels e.g., renewable diesel and biodiesel.

Renewable diesel, which is also called 'green diesel', is a branched paraffin-based, completely deoxygenated fuel that is produced, starting from biological sources, through a hydrogenation reaction where the source reacts with hydrogen to obtain a liquid hydrocarbon fuel. The main advantage of this fuel is the full compatibility with petroleum diesel [1,2]. Research activity on the use of renewable diesel used in blends with petrol diesel showed a decrease in carbon monoxide (CO) and unburned hydrocarbons (HC) emissions [3] and a degradation of the cold properties of green diesel, which was caused by the high content of n-paraffin in the fuel [4].

Biodiesel is a diesel fuel that consists of fatty acid methyl esters, which are generally produced trough a transesterification process of vegetable oils and animal fats. It can be obtained, starting from many sources and, among them, very promising is the fuel obtained from oilseed rape sources that are unsuitable for consumption by humans and animals $[5,6]$ and from mixtures of waste cooking oils (WCO). The use of WCO allows for eliminating the drawback of its disposal; moreover, it is less expensive than virgin oil [7]. Biodiesel from WCO has highlighted its attitude to be used as biofuel in 
diesel engines $[8,9]$. Studies regarding vegetable oil based fuels revealed that the use of neat biodiesel or high percentage of biodiesel blends cannot be employed in diesel engines, since they are responsible for some problems in unmodified diesel engines during their operation due to the high viscosity and density of vegetable oils and to their flow properties and poor volatility. Many engine manufactures approve of biodiesel use only up to a fixed limit. Several investigations studies have highlighted the role of biodiesel on engine emission characteristics and performance. The oxygen in the fuel results in $\mathrm{HC}, \mathrm{CO}$, and particulate matter $(\mathrm{PM})$ reduction; a general increase of nitrogen oxides $\left(\mathrm{NO}_{\mathrm{x}}\right)$ emission is also observed, due to the higher oxygen available in biodiesel. However, biodiesel has a lower caloric value as regarding diesel oil, which thus results in engine power losses when it is blended with conventional diesel fuel [10-14].

The use of an additive could solve the problems related to the use of high biodiesel ratios in blends during the operation in an unmodified engine. Among possible additives, the use of jet fuels, as characterized by lower density and viscosity and better flow properties, could be a very attractive solution. Injection and mixing could be improved by blending biodiesel with aviation fuels. The lower cetane number of these fuels may cause longer ignition delay, but this issue could be balanced by its lower distillation temperature that shortens the ignition delay.

Kerosene use in direct injection diesel engines started at the end of 1980s when by NATO nations introduced the single fuel concept, who decided to use a specific fuel to supply all land based military aircraft and vehicles that aimed at simplifying the logistic chain for petroleum by-products $[15,16]$. F-34 (JP-8) military jet kerosene was selected as the single fuel; it has the same specifications of the F-35 (Jet A), except for those that are related to the use of additives that are used to inhibit system icing and to face with corrosion and thermal stability [17]. JP-8 does not have cetane number specifications; investigations on the effects of the variability of cetane have highlighted that the cetane index varies in the range $31.8-56$, with a mean value of 43.4 , with a great impact on ignition delay, premixed combustion phase, and resulting in large variation of pressure rise rates [16].

Only few investigations have been performed on the use of biodiesel-kerosene blends in compression ignition engines, even if there are many studies on the combustion process and pollutant emissions of different type of biodiesel fuels used in blends with petrol diesel.

Arkoudeas et al. [17] investigated the pollutant emissions from a stationary single cylinder diesel engine in which blends of biodiesels from sunflower and olive oils and JP-8 are used. The use of biodiesel resulted in a reduction of PM and in the limited change of $\mathrm{NO}_{\mathrm{x}}$. The reduction in particulate emissions was the most related to high loads conditions, while the reduction was marginal at low loads. Reference [18] is devoted to present a study on a the use of blends of biodiesel and kerosene in a direct injection diesel engine. The authors found that the percentage of $20 \%$ kerosene and $80 \%$ biodiesel causes a reduction of the pollutant emissions as regards diesel fuel. Llamas et al. [19] used Jet A1 that was blended with bio kerosene; their investigations concluded that biodiesel could be used to partially substitute fossil jet fuels. Chen et al. [20] investigated the emissions from a single cylinder diesel engine that was fueled with kerosene. Such a fuel improved the indicated thermal efficiency and reduced the soot emissions; nitrogen oxide emissions did not have a relevant variation. Aydin et al. [21] tested biodiesel-kerosene blends in a single cylinder diesel engine; kerosene was used to improve biodiesel properties, thus to approach diesel ones. Reference [22] presents an experimental evaluation on the impact of substituting a fraction of fuel by alternative to fossil oils. Gowdagiri et al. [23] studied the impact of jet fuels (JP-5, Jet A), petroleum diesel, and alternative diesel (hydroprocessed algae diesel, hydroprocessed camelina) on ignition delay, emissions, and fuel consumption of a compression ignition engine. The results indicate the relation between fuel properties and engine performance. Rothamer et al. [24] analyzed the ignition delay of diesel and jet fuels in a heavy-duty diesel engine. Reference [25] is devoted to present study on the use of a high percentage of biodiesel in a unmodified diesel engine. Two blends were prepared, in which $80 \%$ biodiesel was contained; in one, it was added to $20 \%$ of kerosene, on the other, it was blended with kerosene $(10 \%)$ and diesel fuel $(10 \%)$. The obtained results 
highlight a reduction of density and viscosity of the blend in which kerosene is used as an additive to biodiesel.

Even though it emerges that some research activity has been performed regarding jet fuels usage in compression ignition engines, studies are limited and most of published data are related to tests at specific value of engine speed, in which biodiesel-kerosene blends are used. Therefore, the necessity of further studies arises.

The topic of this work is to investigate the impact on combustion and emission characteristics of Jet A percentage in a blend containing biodiesel from $\mathrm{WCO}$ and diesel fuel. Aiming at increasing the percentage of renewable fuel, instead of petrol diesel, it was used an innovative fuel (diesel +), in which a fraction of renewable diesel is contained. Previous research activity was devoted to analyze the combustion process and emission characteristics of a diesel engine fuelled with biodiesel from waste cooking oil in blends of petrol diesel and renewable diesel [26]. The results established that the use of a blend of diesel + and biodiesel from WCO enhances PM, HC, and CO emissions in the exhaust as regards petrol diesel; a moderate increase characterizes nitrogen oxides emission. The objective of this work is to present the results of an experimentation, in which Jet A was mixed with diesel + and biodiesel from WCO with the objective of evaluating whether the aviation fuel use allows for the reduction of the typical drawbacks of using biodiesel and the enhancement of the exhaust emissions.

\section{Materials and Methods}

\subsection{Experimental Set-Up}

A Kohler naturally-aspirated two-cylinder, water-cooled, common rail diesel engine is the engine used in the present experimentation; the injection pump delivers fuel with a maximum pressure of up to $80 \mathrm{MPa}$. The electronically controlled injector has five holes, the diameter of each being equal to $0.123 \mathrm{~mm}$. Table 1 reports the engine's main specifications. It was installed in the test cell of the ROMA TRE University-Engineering Department. The engine was connected to the Siemens 1PH7 asynchronous motor and it was instrumented for the complete monitoring of its operation.

Table 1. Engine main data.

\begin{tabular}{cc}
\hline Engine Type & LDW442CRS Naturally Aspirated \\
\hline Cylinders & 2 \\
Bore & $68 \mathrm{~mm}$ \\
Stroke & $60.6 \mathrm{~mm}$ \\
Displacement & $440 \mathrm{~cm} 3$ \\
Compression ratio & $20: 1$ \\
Maximum torque & $21 \mathrm{Nm} @ 2000 \mathrm{rpm}$ \\
Maximum power & $8.5 \mathrm{~kW} @ 4400 \mathrm{rpm}$ \\
\hline
\end{tabular}

HBM T12 was used for torque measurement. The AVL Fuel Balance model 733 was used for supplying the fuel and measuring the consumption, with an accuracy of $0.12 \%$. Pressure transducers were placed in different positions in the intake and exhaust systems. A piezoelectric transducer (AVL GU13P) was installed in the in-cylinder for pressure measurement; a crank encoder was used for recording the crank-angle resolved pressure. AVL Indicom software was used for the data monitoring and acquisition. Further details of the experimental set up may be found in [27].

The exhaust gas composition was analyzed while using the exhaust gas analyzer Bosch BEA352. In this equipment, the $\mathrm{HC}$ analyzer uses a heated flame ionization detector; the $\mathrm{CO}$ measuring instrument uses the non-dispersive infrared detectors, the $\mathrm{NO}_{x}$ analyzer uses the heated chemiluminescence detector. The accuracies of $\mathrm{HC}, \mathrm{CO}$, and NO are $1 \mathrm{ppm}$ vol, $0.001 \%$ vol, and $1 \mathrm{ppm}$ vol, respectively. The size distribution of particulate matter was measured through Cambustion DMS500, which has proven to be characterized by good correlation with regulation compliant systems [28]. The instrument has an uncertainty of about $5 \%$ in particle size measurement for particles that are smaller than $300 \mathrm{~nm}$ 
and about $10 \%$ over the full spectrum for particle number density measurement [29]. Cambustion DMS500 is a classifier column for detecting PM of size in the range $5 \mathrm{~nm}-1 \mu \mathrm{m}$ with a resolution of 16 channels/decade. The incoming exhaust gas passes through a cyclone that is used to remove from the flow all particles larger than $1 \mu \mathrm{m}$. Two dilution stages are applied before the sample gas passes through a corona charger and into the classifier column: the primary dilution rate was set to 5:1; second dilution rate was set to 400:1. Once the charged particles enter the column, they are deflected toward the grounded electrometer rings by their repulsion from the high voltage rod in the center of the device. The particles charge and aerodynamic drag determine their landing position.

\subsection{Fuels and Tests}

Different blends were tested in the experimentation: diesel + (standard ultralow sulfur diesel fuel, ULSD, with $15 \%$ by volume of renewable diesel [30]) was mixed with biodiesel from WCO and Jet A in different percentages.

Renewable diesel was obtained via the Ecofining ${ }^{\mathrm{TM}}$ Process [31] from palm oil, but it may be produced, starting from a wide range of feedstocks. The process consists in subsequent reactions of decarboxylation, hydrodeoxygenation, and hydroisomerization. As the final product, a totally hydrocarbon fuel is obtained, since it does not contain oxygen, unlike traditional biodiesel.

A second-generation biodiesel was used in the experimentation. It was produced from a mixture of waste cooking oils. Some of the treatments were performed to enhance the poor qualities of the initial material and let the oil become similar to a product that was obtained from refined vegetable oils. A cleaning disk separator was used in order to remove the part containing the water-soluble matter and solids. A second disk separator machine allowed for removing the water leftover. Physical deacidification and transesterification process were then performed. The resulting raw biodiesel was distilled, aiming at complying with the reference specifications of biodiesel (EN 14214). In [12], more details of the procedure may be found. Table 2 lists the composition of the utilized biodiesel.

Table 2. Composition of biodiesel from waste cooking oils (WCO).

\begin{tabular}{cc}
\hline Mass Fraction & Biodiesel \\
\hline Carbon & 0.812 \\
Hydrogen & 0.065 \\
Oxygen & 0.117 \\
Sulfur & 0.006 \\
\hline
\end{tabular}

Preliminary investigations were devoted to define the highest percentage of waste cooking oil in the blend that can be used without requiring engine hardware modification, since the compatibility of biodiesel with engine equipment limits the maximum allowable concentration in the fuel. Testing revealed that the maximum biodiesel percentage that can be tested is $40 \%$; higher quantities of biodiesel in the blend are responsible for the degradation of the rubber hoses/seals in the fuel supply system [12].

Jet A is a kerosene-type fuel that is suitable for most jet aircraft. The fuel complies the international requirements, particularly those of the latest versions of the AFQRJOS, the British DEF STAN 91-91 standard, the ASTM D1655 standard, and the NATO F-35 specification.

Table 3 presents the properties of biodiesel from waste cooking oil, renewable diesel, ULSD, diesel + and Jet A.

Table 3. Renewable diesel, ULSD, diesel +, biodiesel from WCO and Jet A properties.

\begin{tabular}{cccccc}
\hline Property & Renewable Diesel [32] & ULSD & Diesel + [32] & Biodiesel from WCO [12] & Jet A \\
\hline density [kg/ $\mathrm{m}^{3}$ at $\left.15^{\circ} \mathrm{C}\right]$ & 780 & 830 & 840 & 877 & 801 \\
lower heating value & 44 & 43.1 & 43.2 & 37.1 & 43.4 \\
[MJ $/ \mathrm{kg}]$ & 80 & 52 & 55 & 56 & 47 \\
cetane number & &
\end{tabular}


Jet $\mathrm{A}$ is characterized by lower viscosity, distillation temperature range, and cetane number as regards ULSD fuel; the lower density, viscosity, and surface tension cause its better atomization when compared to diesel fuel [20].

Stationary tests were performed in the entire speed range of the engine, from $2400 \mathrm{rpm}$ to $3600 \mathrm{rpm}$, with a step of $300 \mathrm{rpm}$. The load value was fixed at $80 \%$ as regards the torque available at the full load condition when the engine was supplied with petrol diesel; this allowed for imposing on the engine an high value of torque that was equal for all of the tested fuels. The injection strategy and settings were not modified to account for the fuel properties (details are reported in Table 4).

Table 4. Injection settings.

\begin{tabular}{ccccc}
\hline $\begin{array}{c}\text { Engine Speed } \\
{[\mathbf{r p m}]}\end{array}$ & $\begin{array}{c}\text { Torque } \\
{[\mathbf{N m}]}\end{array}$ & $\begin{array}{c}\text { SOI pre } \\
\text { [cad BTDC] }\end{array}$ & $\begin{array}{c}\text { SOI Main } \\
{[\text { cad BTDC] }}\end{array}$ & $\begin{array}{c}\text { Prail } \\
{[\text { bar] }}\end{array}$ \\
\hline 2400 & 18.2 & 18.5 & 5.9 & 620 \\
2700 & 19.0 & 18.4 & 5.9 & 610 \\
3000 & 17.5 & 15.5 & 6.0 & 610 \\
3300 & 17.0 & 16.8 & 6.3 & 630 \\
3600 & 15.2 & 18.1 & 6,7 & 650 \\
\hline
\end{tabular}

The engine was allowed to run for about 10 min during the experimentation, before starting a new test, in order to consume the remaining fuel from previous testing. Once stable condition with the new fuel was obtained, measurements have begun with a specific blend.

For each test, the average of the recorded data was computed, thus to reduce the engine cycle irregularities once the signals were acquired ( 25 cycles were used, the increase in this number did not change the feature of the trends).

\section{Results}

The first part of this section is devoted to analyzing the impact on combustion process and emissions characteristics of Jet A percentage in the blends with diesel +. During the experimental tests, two blends containing $10 \%$ and $20 \%$ by volume (named DK10 and DK20, respectively) have been used and their performance is compared to those that were obtained by fueling the engine with net diesel+. The second part of this section focuses on the evaluation of the possible use of aviation fuel to reduce the typical drawback of using biodiesel (difficulties in atomization and mixing with air caused by its high viscosity, low volatility) and to enhance the emissions. The results obtained during the experimentation of blends in which Jet A is mixed with diesel + and biodiesel from WCO are presented.

\subsection{Jet A blended with diesel +}

The investigation is based on the results of a previous activity on the same engine, which pointed out how using diesel + on replacement of ULSD allows for a reduction of CO, HC, and soot emissions, along with an increase of $\mathrm{NO}_{\mathrm{x}}$ emission [26]. Jet $\mathrm{A}$ was blended with diesel +; the combustion and pollutant emissions were analyzed with the aim of evaluating the impact of different percentages of Jet A on diesel + behaviour as a function of engine speed condition.

Figure 1 shows CO and HC emissions from diesel + used net or blended with $10 \%$ and $20 \%$ by the volume of Jet $\mathrm{A}$. The air fuel ratio and the available temperature in the cylinder are the parameters that primarily govern the emission. Data related to carbon monoxide exhibit a reduction of the emission as the percentage of Jet $A$ in the blend increases, especially at low engine speed values. This behavior is caused by the high volatility of Jet A, which promotes the combustion; at higher engine speed, such an effect is balanced by the cetane number of the aviation fuel and its longer ignition delay, which promote $\mathrm{CO}$ emission. The blending of Jet $\mathrm{A}$ is responsible for an increase of hydrocarbon emissions, except for lowest values of speed when DK20 is used; this feature could be caused by the longer ignition delay of 
Jet A and incomplete combustion. The HC emissions are related to the locally lean and locally high rich region of the chamber; they are also attributed to the flame extinction in the cold regions of the cylinder.
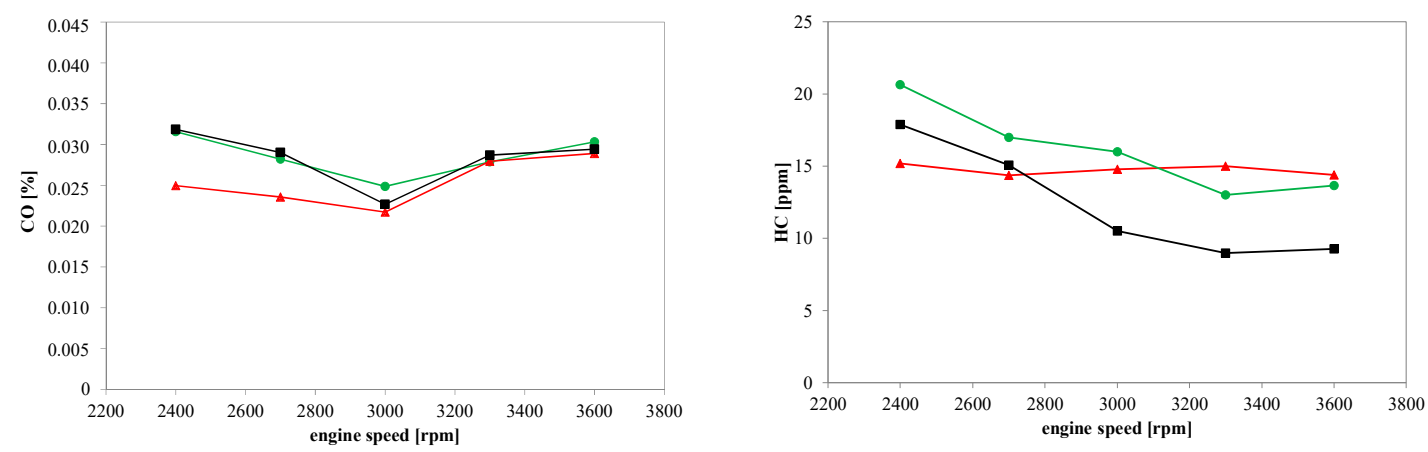

- $\operatorname{diesel}+\quad$ DK10 $\Delta \mathrm{DK} 20$

Figure 1. Carbon monoxide $(\mathrm{CO})$ and unburned hydrocarbons $(\mathrm{HC})$ variation with engine speed, $80 \%$ load.

In Figure 2, the variation of $\mathrm{NO}$ emission as function of the engine speed is shown $\left(\mathrm{NO}_{\mathrm{x}}\right.$ are expressed as NO equivalent). All of the curves present a decreasing trend as the engine speed increases. This behaviour is due to the reduction of ignition delay that is caused by the increase of gas motion in the chamber at higher values of engine speed. Moreover, the residence time at high temperature within the cylinder is reduced with the increase of engine speed, which resulted in a decrease of $\mathrm{NO}_{\mathrm{x}}$ emission.

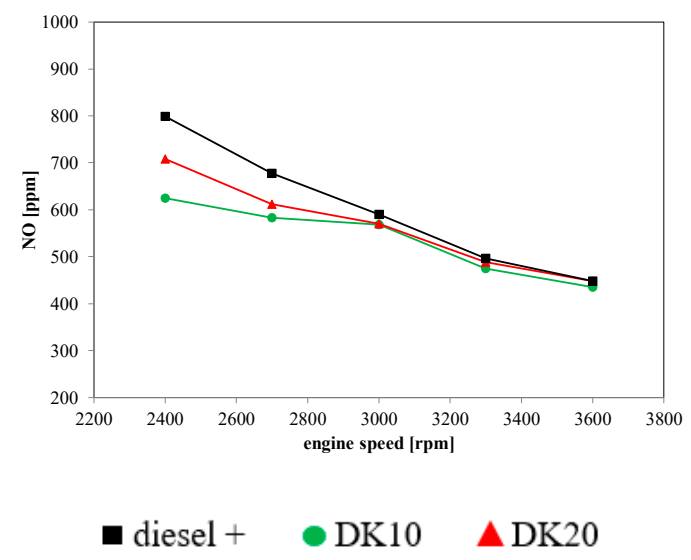

Figure 2. NO variation with engine speed, $80 \%$ load.

The effect of adding Jet $\mathrm{A}$ to the fuel is a significant reduction in the emission, especially at lower engine speed values. The primary factors that affect $\mathrm{NO}_{\mathrm{x}}$ formation are the availability of oxygen and the high combustion temperature. Both diesel and aviation fuel have limited oxygen content and similar air/fuel ratio; for diesel +, the enhanced portion of premixed combustion at $80 \%$ of load is responsible for the higher temperature in the cylinder, thus contributing to the larger amount of $\mathrm{NO}_{x}[26]$.

Figure 3 presents the effect of Jet $\mathrm{A}$ on the particulate emission of the engine. Looking at soot concentration in the exhaust, all of the traces show an increase in the values with the engine speed, accordingly with literature results on the relation between particulate emission and engine speed [14,33]. This behavior is to ascribe to the balance between the reduction of time available for air-mixing and combustion, which penalizes combustion completeness, and the enhancement of turbulence, which improves the combustion completeness. 

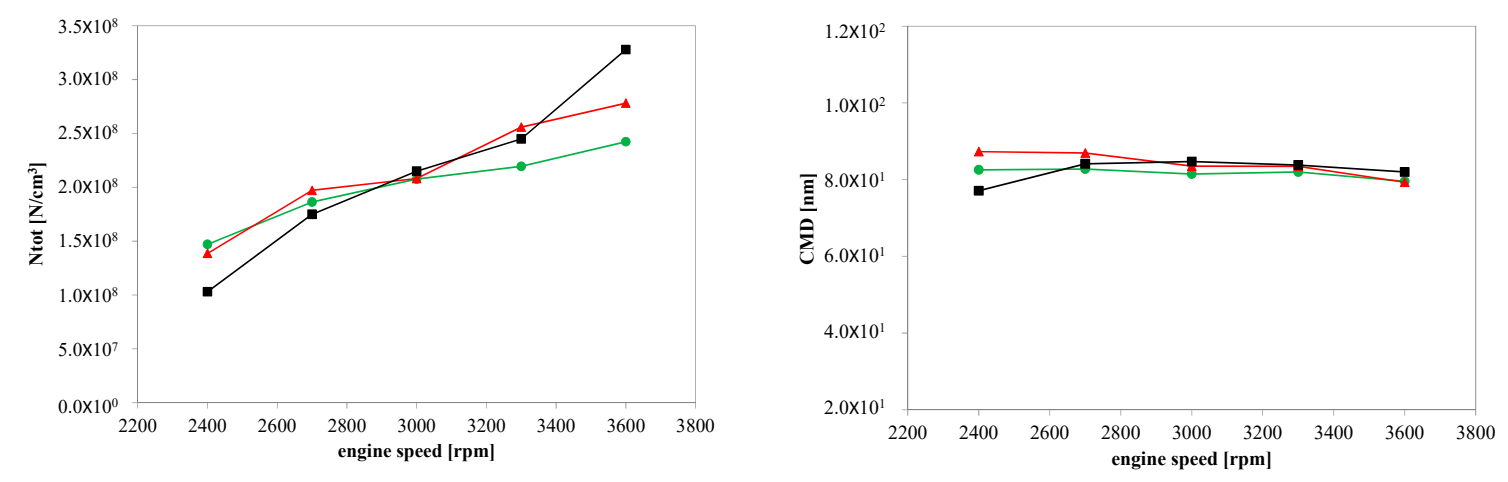

- diesel + DK10 $\Delta$ DK20

Figure 3. Particle number concentration and mean diameter variation with engine speed, $80 \%$ load.

Mixing Jet A to diesel + causes an increase of particulate emissions at lower engine speed values. This is caused by the properties of the fuels: the lower cetane of Jet A increases the ignition delay and the ignition occurs later than diesel +; the energy released during premixed combustion is increased, resulting in higher pressure and temperature in the cylinder, according to [34].

Regarding particle size, Figure 3 shows the influence of fuel type on the mean diameter of accumulation mode as a function of engine speed. A bimodal distribution of PM size was observed for tested blends. All of the operative conditions of the engine are characterized by a predominance of accumulation mode as regards the nucleation one. The court mean diameter (CMD) has an average value around $80 \mathrm{~nm}$ and it not exhibit significant changes with the fuel.

The combustion development was analyzed by means of the Rate of Heat Release curve, aimed at deeper insight into the impact of fuel properties on exhaust pollutants formation. The acquired in-cylinder pressure was used to compute the heat release during the combustion. A thermodynamic model allowed for the computation; the instantaneous heat loss to the cylinder wall was evaluated by the Woschni model [35].

In this study, the injection strategy was not changed, since the aim of the research was not to optimize the injection setting for the different blends, but it was to investigate the engine behaviour with an unmodified ECU setting. A two-stage injection was imposed on the engine; during tests, the shots setting was modified for each operative point, but it was not changed with the fuel type. $1 \mathrm{~mm}^{3} /$ stroke of fuel was delivered during pre-injection; during main injection, adjustment of fuel quantity was allowed to impose the same torque value, no matter the fuel type is (Table 5 presents the ECU settings for the injected fuel quantity).

Table 5. Injected quantity.

\begin{tabular}{cccccc}
\hline $\begin{array}{c}\text { Engine Speed } \\
{[\mathbf{r p m}]}\end{array}$ & $\begin{array}{c}\text { Air Mass } \\
{[\mathbf{k g} / \mathbf{h}]}\end{array}$ & $\begin{array}{c}\text { Q pre } \\
{\left[\mathbf{m m}^{\mathbf{3}} / \mathbf{s t r}\right]}\end{array}$ & $\begin{array}{c}\text { Q main Diesel } \\
\mathbf{+}\left[\mathbf{m m}^{\mathbf{3}} \mathbf{s t r}\right]\end{array}$ & $\begin{array}{c}\text { Q pre DK10 } \\
{\left[\mathbf{m m}^{3} / \mathbf{s t r}\right]}\end{array}$ & $\begin{array}{c}\text { Q Main DK20 } \\
{\left[\mathbf{m m}^{3} / \mathbf{s t r}\right]}\end{array}$ \\
\hline 2400 & 35,0 & 1 & 11.9 & 12.0 & 11.9 \\
2700 & 38,9 & 1 & 10.3 & 10.7 & 10.6 \\
3000 & 42,7 & 1 & 8.8 & 9.2 & 9.1 \\
3300 & 46,5 & 1 & 8.9 & 8.7 & 9.2 \\
3600 & 50,4 & 1 & 8.3 & 8.1 & 8.3 \\
\hline
\end{tabular}

Figures 4 and 5 present the Rate of Heat Release and the in-cylinder pressure trends that were obtained for the tested fuels under a fixed value of engine speed. In Figure 4, the energizing timings of the pre and main injection are plotted as boxes overlapped to the curves. 


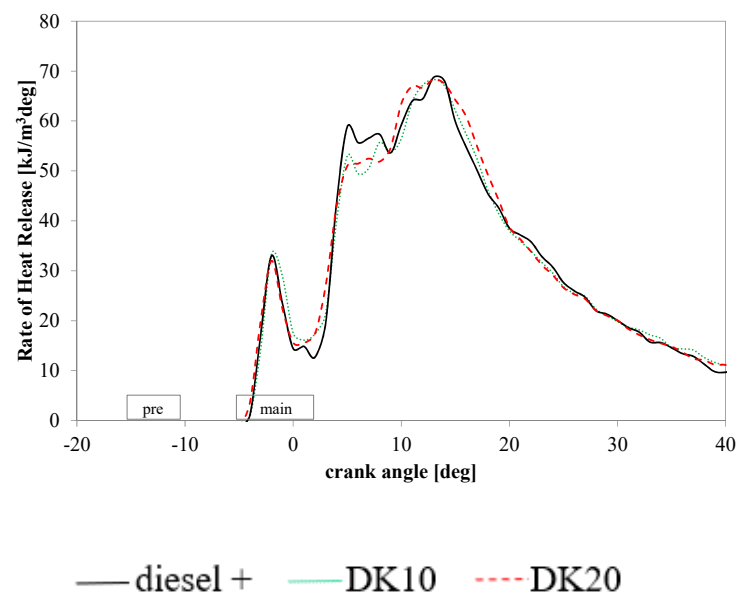

Figure 4. Rates of heat release at $3300 \mathrm{rpm}, 80 \%$ load.

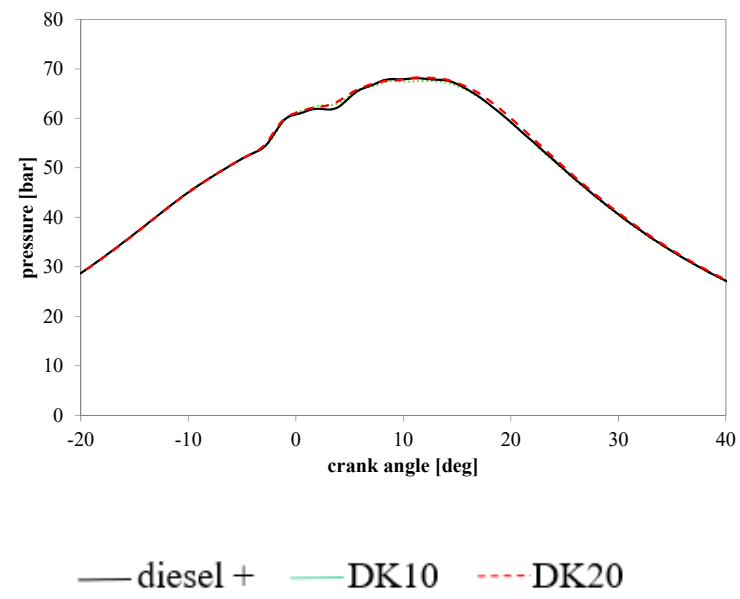

Figure 5. In-cylinder pressure at $3300 \mathrm{rpm}, 80 \%$ load.

It has to be considered how injection works: ECU establishes the duration of pre-injection process, thus to deliver $1 \mathrm{~mm}^{3}$ of fuel in order to analyze the curves. When blends of diesel + and Jet $A$ are used, the lower values of density and viscosity of aviation fuel alter the properties of the blends. The unchanged energizing timings injection timings cause a longer duration of injection, according to [36]. These variations are responsible for a modification of the mass that is delivered during pre-injection; during the main injection, the amount of delivered fuel is established by ECU to guarantee the required torque value. The fuel properties also affect spray penetration, velocity, and angle [36].

When DK10 is used, Jet A in pre-injected fuel delays the first peak of heat release curve. A larger amount of heat is released before TDC as regards diesel + . The high temperature allows for a fast evaporation of diesel + in the blend, thus promoting the oxidation reactions. The lower cetane number characterizing Jet A causes an extension of the heat release curve that is moved towards the expansion stroke. When DK20 is used, the heat release released before TDC is increased as regards diesel+, the effect of cetane number on moving the combustion towards the expansion stroke is more evident as regards the DK10 blend. Mixing Jet A in the blend makes the subsequent combustion phases more contiguous, as in-cylinder pressure curves show. 


\subsection{Jet A blended with Diesel + and Biodiesel from $W C O$}

Experimentation was carried out with the aim of using Jet $A$ as additive to enhance the performance of blends of biodiesel and diesel +, since mixing Jet A with diesel + demonstrated allowing a reduction of $\mathrm{NO}_{\mathrm{x}}$.

At first, it was decided to mix a fixed percentage of Jet $\mathrm{A}$ in two blends, which differentiate for the biodiesel/diesel + percentage. $10 \%$ by volume of Jet A was chosen, since it allows obtaining a larger reduction of $\mathrm{NO}_{\mathrm{x}}$ and a moderate increase of particulate matter as regards $20 \%$. The range of biodiesel blending ratio was fixed by considering that $40 \%$ is the maximum value that can be ready to use in the actual engine without requiring any hardware modification; values of less than $20 \%$ have demonstrated to have very low impact on the fuel behaviour [12]. Subsequently, a fixed amount of biodiesel was mixed with blends of Jet A and diesel + (two percentages of Jet A were considered).

Figures 6-8 present the emission characteristics of the following fuels (percentages by volume):

- $\quad$ DB20K10: 70\% diesel,$+ 20 \%$ biodiesel from waste cooking oil, $10 \%$ Jet A

- $\quad$ DB40K10: $50 \%$ diesel,$+ 40 \%$ biodiesel from waste cooking oil, $10 \%$ Jet A

- DB20: $80 \%$ diesel,$+ 20 \%$ biodiesel from waste cooking oil

- $\quad$ DB40: $60 \%$ diesel,$+ 40 \%$ biodiesel from waste cooking oil

Under the same amount of biodiesel, substituting a fraction of diesel + with Jet A causes an increase of $\mathrm{CO}$ in the exhaust (Figure 6); HC emissions remain almost unchanged. Under the same amount of Jet $\mathrm{A}$ in the fuels, the increase of biodiesel content is responsible for a reduction of the in-cylinder temperature according with [12], to ascribe to the lower heating value of biodiesel, which reduces the amount of energy that is released. The lower temperature causes the increase of hydrocarbons and carbon monoxide emissions, despite the biodiesel higher content of oxygen that becomes less effective. This behaviour is consistent with [16], in which the results that are related to a constant engine speed value are presented.
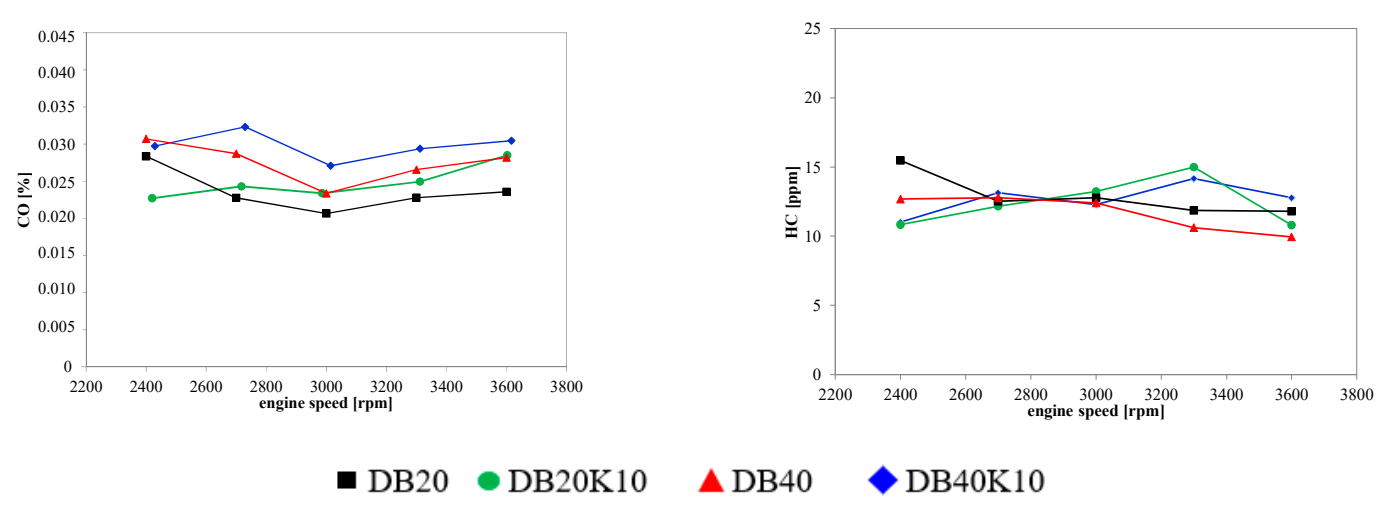

Figure 6. $\mathrm{CO}$ and $\mathrm{HC}$ variation as function of engine speed, $80 \%$ load.

In Figure 7, $\mathrm{NO}_{\mathrm{x}}$ emission in terms of $\mathrm{NO}$ equivalent is plotted as a function of engine speed.

At a lower engine speed, blending with Jet $\mathrm{A}$ allows for a reduction of the emission. The reason is thought to be related to the faster vapour mixing and the burning properties of Jet $\mathrm{A}$, which reduces the time that is available for nitrogen oxides production [25]. At higher engine speed, when Jet A is used with biodiesel and diesel + , its longer ignition delay is responsible for a larger amount of fuel in the chamber. Higher combustion temperatures are reached, thus causing $\mathrm{NO}_{\mathrm{x}}$ emission increase, which is in agreement with experimental data related to the cetane number effect on engine performance and emissions [34].

Concerning particulate matter emissions, they are generally reduced by adding biodiesel, which is caused by the oxygen presence in biodiesel molecules. Figure 8 shows the effect of biodiesel and Jet $\mathrm{A}$ on the particle number and mean diameter. When Jet A is mixed in the blend, it is responsible 
for a different behaviour as a function of the engine speed. At lower engine velocity, an increase of particulate matter concentration is observed for both blends with Jet A. Substituting diesel + with Jet A at higher values of engine speed causes a reduction of soot emission, probably to ascribe to the higher fuel volatility of Jet A and the longer ignition delay that lead to better fuel-air mixing. The mixing enhancement entails that fewer fuel-rich pockets exist in the chamber thus causing a reduced formation of soot.

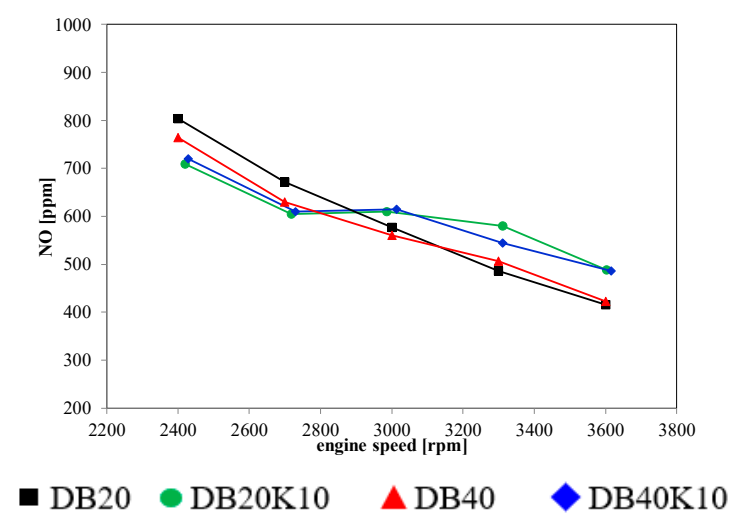

Figure 7. NO variation as function of engine speed, $80 \%$ load.
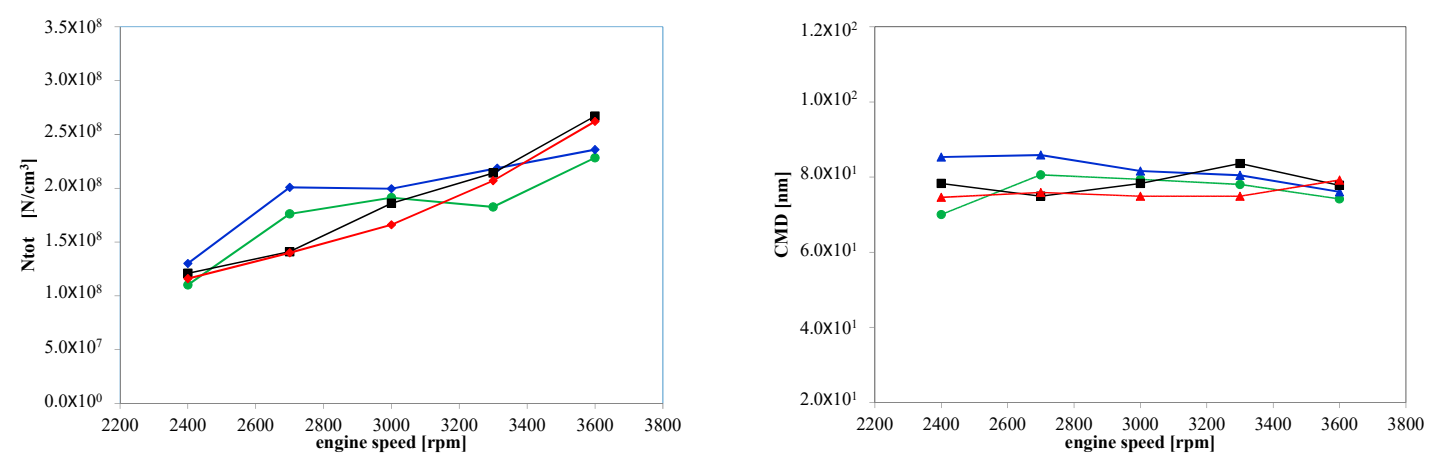

- DB20 DB20K10

$\Delta \mathrm{DB} 40$

$\mathrm{DB} 40 \mathrm{~K} 10$

Figure 8. Particle number concentration and mean diameter variation with engine speed, $80 \%$ load.

The mean diameter of emitted particle is characterized by values of around $80 \mathrm{~nm}$ for all blends. Higher diameters characterize the emission of DB40K10 (diesel $+50 \%$, biodiesel $40 \%$, and Jet $10 \%$ by volume) in almost all the values of tested engine speed.

Aimed at deeper investigation the impact of Jet A in the blend, some tests have been performed with a variation of aviation fuel percentage in a mixture containing $30 \%$ by volume of biodiesel. Such a value was selected based on the previously presented results, which have demonstrated how this percentage behaves as a compromise between 20 and $40 \%$. Investigations were devoted to evaluate the effect of Jet A percentage in a blend in which the amount of biodiesel was fixed (Jet A was increased in detriment of diesel + quantity). Three blends were tested (percentages by volume):

- $\quad$ DB30: $70 \%$ diesel,$+ 30 \%$ biodiesel from waste cooking oil

- $\quad$ DB30K10: $60 \%$ diesel +, biodiesel from WCO 30\%, Jet A $10 \%$ by volume

- DB30K20: diesel $+50 \%$, biodiesel from $\mathrm{WCO} 30 \%$, Jet A $20 \%$ by volume

Figure 9 shows the $\mathrm{CO}$ and $\mathrm{HC}$ concentration in the exhaust. Adding Jet A causes a small increase of both emissions. 

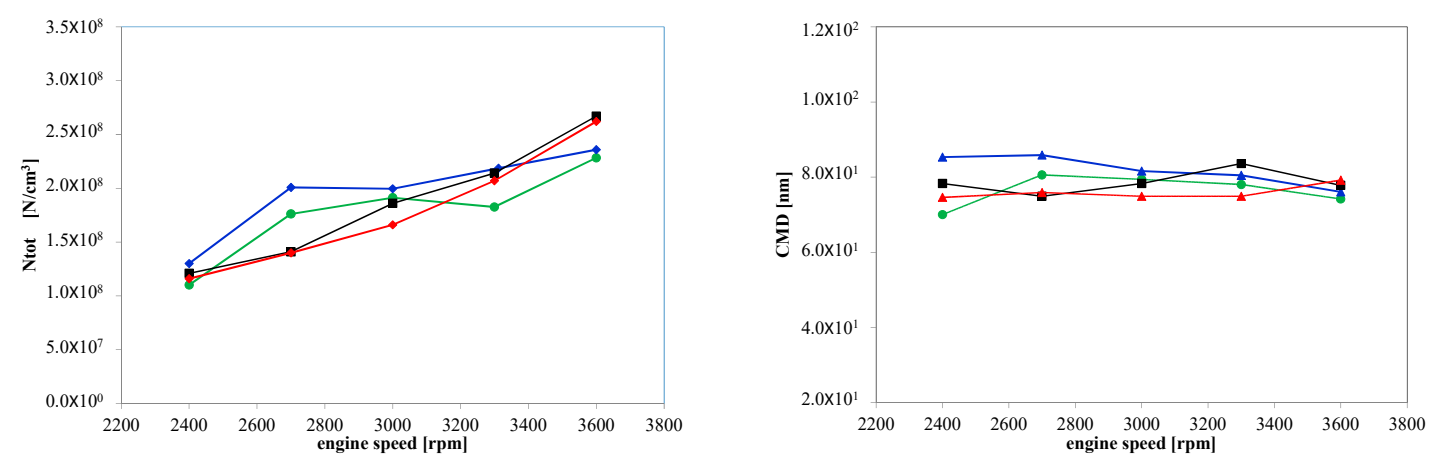

- DB20 DB20K10

$\Delta \mathrm{DB} 40$

DB40K10

Figure 9. CO and HC variation as function of engine speed, $80 \%$ load.

Figure 10 shows that the effect of Jet $\mathrm{A}$ on $\mathrm{NO}_{\mathrm{x}}$ emission is almost negligible.

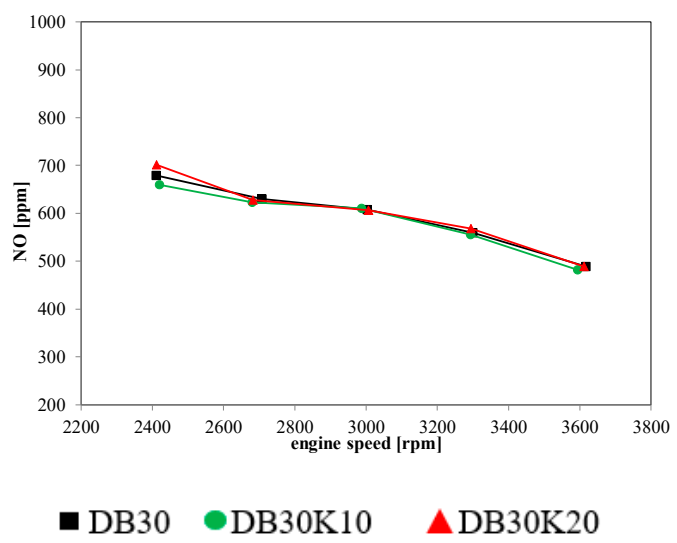

Figure 10. NO variation with engine speed at $80 \%$ load.

Concerning particulate emission (Figure 11), a reduction was obtained in the complete engine speed range while adding Jet $\mathrm{A}$ in the fuel. The decrease in soot is particularly significant for DB30K10.
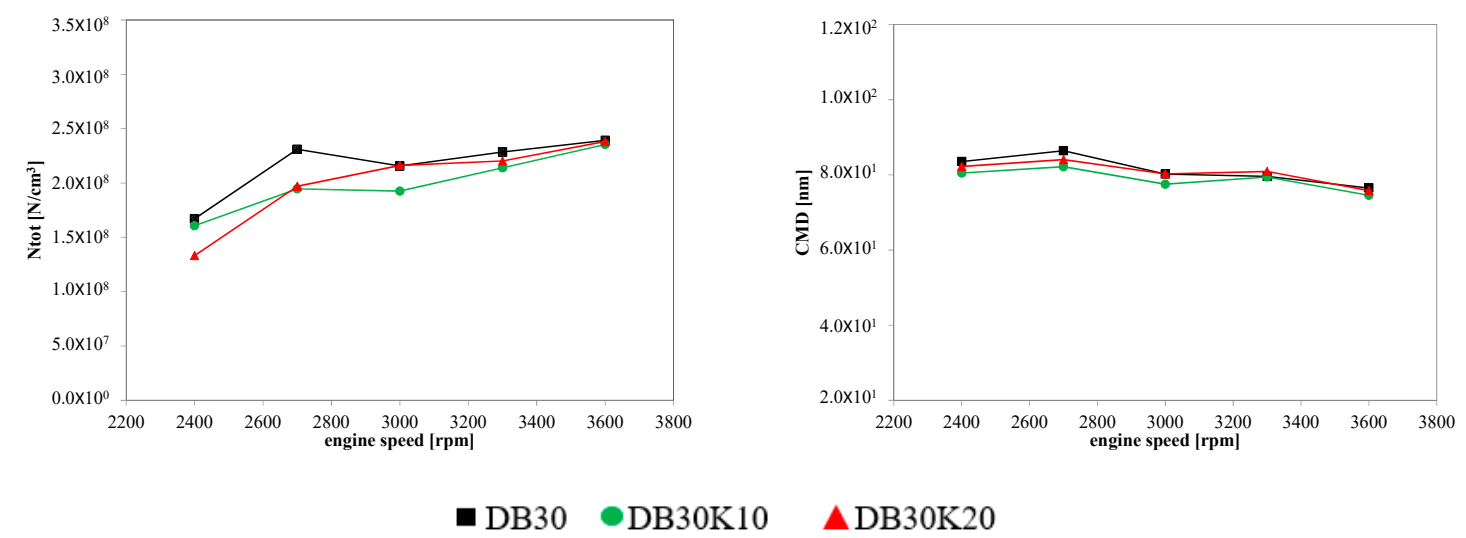

$\Delta \mathrm{DB} 30 \mathrm{~K} 20$

Figure 11. Particle number concentration and mean diameter variation as function of engine speed, $80 \%$ load.

Particle diameters have a moderate decrease with the engine speed, but there are almost no difference among the fuels. 


\section{Conclusions}

An experimental analysis was carried out to evaluate the potential use in diesel engines of Jet $\mathrm{A}$, along with blends of petrol diesel, renewable diesel, and biodiesel.

Previous research activity highlighted that biodiesel use in blend with renewable diesel and petrol diesel enhances carbon monoxide, hydrocarbons, and particulate matter emissions as regards petrol diesel with an increase of nitrogen oxides emission. Moreover, a maximum value of biodiesel amount in the blend was defined, in order to guarantee a correct engine operation without the need of hardware modification.

Testing was performed to analyze whether mixing Jet $\mathrm{A}$ in a blend containing biodiesel allows for mitigating the drawbacks of biodiesel and obtaining an improvement of the exhaust emission.

Blends containing different percentages of Jet A and biodiesel from WCO were investigated as a function of the engine speed, keeping the load condition constant. The results indicate that, when $10 \%$ of Jet A is added to blends containing diesel + and biodiesel from WCO (DB20K10, DB40K10), the relation between emissions and engine speed remains almost unchanged as regards the trends that were observed with blends of diesel + and WCO biodiesel. CO and HC have a weak dependence on the engine speed values; NO is characterized by a reduction with an engine speed increase. Particle number density in the exhaust shows an increment with the engine speed increase. At lower values of engine speed NO is reduced, but particle number concentration increases; at higher values of engine speed, these emissions behave in the opposite way.

The experimental data indicate that mixing diesel + with $30 \%$ by volume of biodiesel and $10 \%$ or $20 \%$ of Jet $\mathrm{A}$ allows for an enhancement of $\mathrm{NO}_{x}$ emission. In the exhaust flow, the concentration of soot was reduced, especially at lower values of engine speed; the number of particles decreased and the mean diameters of particle remain almost unchanged.

The test results suggest that using Jet A could be a way to increase the amount of renewable fuel in diesel engines, without penalizing the pollutant emission.

Author Contributions: Conceptualization: G.C. and O.C.; Investigation: F.P.; Formal analysis: O.C.; Resources: O.C.; Supervision: G.C.; Visualization: O.C.; Writing—original draft O.C.; Writing—review \& editing: O.C.

Funding: This research received no external funding.

Conflicts of Interest: The authors declare no conflicts of interest.

\section{References}

1. Vonortas, A.; Papayannakos, N. Comparative analysis of biodiesel versus green diesel. Wiley Interdiscip. Rev. Energy Environ. 2014, 3, 3-23. [CrossRef]

2. Douvartzides, S.L.; Charisiou, N.D.; Papageridis, K.N.; Goula, M.A. Green Diesel: Biomass Feedstocks, Production Technologies, Catalytic Research, Fuel Properties and Performance in Compression Ignition Internal Combustion Engines. Energies 2019, 12, 809. [CrossRef]

3. Knothe, G. Biodiesel and renewable diesel: A comparison. Prog. Energy Combust. Sci. 2010, 36, 364-373. [CrossRef]

4. Šimáček, P.; Kubička, D.; Šebor, G.; Pospíšil, M. Fuel properties of hydroprocessed rapeseed oil. Fuel 2010, 89, 611-615. [CrossRef]

5. Öztürk, E. Performance, emissions, combustion and injection characteristics of a diesel engine fuelled with canola oil-hazelnut soapstock biodiesel mixture. Fuel Process. Technol. 2015, 129, 183-191. [CrossRef]

6. Ge, J.C.; Kim, H.Y.; Yoon, S.K.; Choi, N.J. Reducing volatile organic compound emissions from diesel engines using canola oil biodiesel fuel and blends. Fuel 2018, 218, 266-274. [CrossRef]

7. Phan, A.N.; Phan, T.M. Biodiesel production from waste cooking oils. Fuel 2009, 87, 3490-3496. [CrossRef]

8. Demirbas, A. Progress and recent trends in biodiesel fuels. Energy Convers. Manag. 2009, 50, 14-34. [CrossRef]

9. Can, O. Combustion characteristics, performance and exhaust emissions of a diesel engine fueled with a waste cooking oil biodiesel mixture. Energy Convers. Manag. 2014, 87, 676-686. [CrossRef] 
10. Song, H.; Tompkins, B.T.; Bittle, J.A.; Jacobs, T.J. Comparisons of NO emissions and soot concentrations from biodiesel fuelled diesel engine. Fuel 2012, 96, 446-453. [CrossRef]

11. An, H.; Yang, W.M.; Chou, S.K.; Chua, K.J. Combustion and emissions characteristics of diesel engine fueled by biodiesel at partial load conditions. Appl. Energy 2012, 99, 363-371. [CrossRef]

12. Chiatti, G.; Chiavola, O.; Palmieri, F.; Albertini, S. Combustion and emissions characterization of biodiesel blends in a city-car Engine. Energy Fuels 2014, 28, 5076-5085. [CrossRef]

13. Chiatti, G.; Chiavola, O.; Palmieri, F. Impact of Waste Cooking Oil in Biodiesel Blends on Particle Size Distributions from a City-Car Engine. J. Energy Inst. 2018, 91, 262-269. [CrossRef]

14. Xue, J.; Grift, T.E.; Hansen, A.C. Effect of biodiesel on engine performances and emissions. Renew. Sustain. Energy Rev. 2011, 15, 1098-1116. [CrossRef]

15. Lin Tay, K.; Yu, W.; Zhao, F.; Yang, W. From fundamental study to practical application of kerosene in compression ignition engines: An experimental and modeling review. Proc. Inst. Mech. Eng., Part D J. Automob. Eng. 2019. [CrossRef]

16. Murphy, L.; Rothamer, D. Effects of Cetane Number on Jet Fuel Combustion in a Heavy-Duty Compression Ignition Engine at High Load. SAE Tech. Pap. 2011, 1, 0335.

17. Arkoudeas, P.; Kallingeros, S.; Zannikos, F.; Georgios, A.; Dimitrios, K.; Dimitrios, M.K.; Evripidis, L. Study of using JP-8 aviation fuel and biodiesel in CI engines. Energy Convers. Manag. 2003, 44, 1013-1025. [CrossRef]

18. Roy, M.M.; Wang, W.; Alawi, M. Performance and emissions of a diesel engine fuelled by biodiesel-diesel, biodiesel-diesel-additive and kerosene-biodiesel blends. Energy Convers. Manag. 2014, 84, 164-173. [CrossRef]

19. Llamas, A.; García-Martínez, M.-J.; Al-Lal, A.-M.; Canoira, L.; Lapuerta, M. Biokerosene from coconut and palm kernel oils: Production and properties of their blends with fossil kerosene. Fuel 2012, 102, 483-490. [CrossRef]

20. Chen, L.; Ding, S.; Liu, H.; Lu, Y.; Li, Y.; Roskilly, A.P. Comparative study of combustion and emissions of kerosene (RP-3), kerosene-pentanol blends and diesel in a compression ignition engine. Appl. Energy 2017, 203, 91-100. [CrossRef]

21. Aydin, H.; Bayindir, H.; İlkiliç, C. Emissions From an Engine Fueled With Biodiesel-kerosene Blends. Energy Sour. Part A Recovery Util. Environ. Eff. 2010, 33, 130-137. [CrossRef]

22. Venkanna, B.K.; Venkataramana Reddy, C. Performance, emission and combustion characteristics of DI diesel engine running on blends of hone oil/ diesel fuel/kerosens/DMC. Int. J. Agric. Biol. Eng. 2011, 4, 48-57.

23. Gowdagiri, S.; Cesari, X.M.; Huang, M.; Oehlschlaeger, M.A. A diesel engine study of conventional and alternative diesel and jet fuels: Ignition and emissions characteristics. Fuel 2014, 136, 253-260. [CrossRef]

24. Rothamer, D.A.; Murphy, L. Systematic study of ignition delay for jet fuels and diesel fuel in a heavy-duty diesel engine. Proc. Combust. Inst. 2013, 34, 3021-3029. [CrossRef]

25. Bayındır, H.; Zerrakki Işık, M.; Argunhan, Z.; Yücel, H.L.; Aydın, H. Combustion, performance and emissions of a diesel power generator fueled with biodiesel-kerosene and biodiesel-kerosene-diesel blends. Energy 2017, 123, 241-251. [CrossRef]

26. Chiavola, O.; Recco, E. Emission performance of a Diesel engine fuelled with petrol diesel, green diesel, and waste cooking oil blends. J. Combust. 2018. [CrossRef]

27. Chiatti, G.; Chiavola, O.; Recco, E. Analysis of the Relationship between Noise Emission and In-Cylinder Pressure in a Small Displacement Diesel Engine. SAE Tech. Pap. 2014, 1, 1364.

28. Cavina, N.; Poggio, L.; Bedogni, F.; Rossi, V.; Stronati, L. Benchmark Comparison of Commercially Available Systems for Particle Number Measurement. SAE Tech. Pap. 2013, 24, 0182.

29. Anbari, M.; Attar, M.; Xu, H. Correlations between particulate matter emissions and gasoline direct injection spray characteristics. J. Aerosol Sci. 2016, 102, 128-141. [CrossRef]

30. Kalnes, T.; Marker, T.; Shonnard, D.R. Green Diesel: A Second Generation Biofuel. Int. J. Chem. React. Eng. 2007. [CrossRef]

31. Baldiraghi, F.; Di Stanislao, M.; Faraci, G.; Perego, C. Ecofining: New Process for Green Diesel Production from Vegetable Oil. In Sustainable Industrial Chemistry; Wiley-VCH Verlag GmbH \& Co. KGaA: Weinheim, Germany, 2009.

32. Eni Oil Products. Available online: https://oilproducts.eni.com/it_IT/prodotti/carburanti-e-combustibili/ trazione/gasolio/eni-diesel (accessed on 20 June 2019).

33. Yehliu, K.; Boehman, A.L.; Armas, O. Emissions from different alternative diesel fuels operating with single and split fuel injection. Fuel 2010, 89, 423-437. [CrossRef] 
34. Li, R.; Wang, Z.; Ni, P.; Zhao, Y. Effects of cetane number improvers on the performance of diesel engine fueled with methanol/biodiesel blend. Fuel 2014, 128, 180-187. [CrossRef]

35. Heywood, J.E. Internal Combustion Engine Fundamentals; McGraw-Hill Education: New York, NY, USA, 1989.

36. Yu, W.; Yang, W.; Tay, K.; Mohan, B.; Zhao, F.; Zhang, Y. Macroscopic spray characteristics of kerosene and diesel based on two different piezoelectric and solenoid injectors. Exp. Therm. Fluid Sci. 2016, 76, 12-23. [CrossRef]

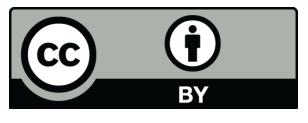

(C) 2019 by the authors. Licensee MDPI, Basel, Switzerland. This article is an open access article distributed under the terms and conditions of the Creative Commons Attribution (CC BY) license (http://creativecommons.org/licenses/by/4.0/). 